\title{
Estimation of Phytoconstituents in Leaf Extract of Morus AlbaL
}

\author{
Sabira Mushtaq ${ }^{1}$, Shail Bala Sanghi ${ }^{2}$ \\ Govt. M.L.B. P. G Girls. College Bhopal (M.P.) India
}

\begin{abstract}
Leaves ofMorus alba L. arequite evident from the literatures surveyed that these plants possess antibacterial, and antioxidant activity and therefore the extracts of these herbs alone or in combination may have the potential to treat many disease in an effective manner without exhibiting side effect or toxicity as indicated by synthetic molecules. The aim of our study is to provide scientific evidence concerned to the medicinal values of this herb.In this study, the ethanolic extract of leaves from Morus alba L., a traditional Chinese medicine, was evaluated for their Phytochemical analysis. Phytochemical analysis revealed the presence of phenols, flavonoids, alkaloids, and proteins in the extract;Ethanolic extracts showed higher contents of both total phenolics and flavonoids.
\end{abstract}

Keywords: White mulberry ,Morus alba L., Leaves, Phytochemical analysis, Preliminary screening.

\section{Introduction}

Medicinal plants have been source of wide variety of biologically active compounds for many centuries and used extensively as crude material or as pure compounds for treating various disease conditions (Arif et al., 2009).The use of herbal medicines becoming popular due to toxicity and side-effects of allopathic medicines. Medicinal plants play an important role in the development of potent therapeutic agents. There are over 1.5 million practitioners of traditional medicinal system using medicinal plants in preventive, promotional and curative applications (Dasilva 1999). India with its biggest repository of medicinal plants in the world may maintain an important position in the production of raw materials either directly for crude drugs or as the bioactive compounds in the formulation of pharmaceuticals and cosmetics etc (Tiwari 2008).

Morus alba L. (white mulberry) is monoecious, deciduous tree and is of medium size with a height of about $30 \mathrm{~m}$ and width of about $1.8 \mathrm{~m}$, it is distributed throughout Asia, Africa, Europe and South and North America and found in wide range of tropical areas and in hilly areas of Himalayas at the height of $3300 \mathrm{~m}$. It is reported that in Chinese medicine white mulberry has been widely used in medicine since 659 A.D and Chinese pharmacopoeia lists the root bark, stem, fruits and leaves as a constituent in medicinal preparations (Kumar and Chauhan, 2008). Other common name of white mulberry is silkworm mulberry and in Urdu, Persian and Hindi it is commonly called as shahtoot.

Use of nonconventional feeds is gaining popularity in many developing countries of world because by feeding rich protein diet, the supply of amino acids to milking animals enhanced the milk production (Mohammadabadi and Chaji, 2012). This is due the presence of steroids, flavonoids, amino acids, vitamins, triterpenes and other trace elements which show valuable effects (Deshmukh et al., 1993). M. alba is reported to have neuroprotective, skin tonic, antioxidant, anti-hyperglycemic, antibacterial, antihypertensive, and anti-hyperlipidemic activities (Nomura et al., 1980; Butt et al., 2008; Sun et al., 2011).
The medicinal worth of various herbal or indigenous plants depends upon their chemical substances that generate a distinct physiological action in the human body (Gutierrez-Uribe et al., 2011).Wide range of medicinal activities have been credited to the different parts of the mulberry plant (Datta, 2000), the leaves of M. alba are dried and used in infusions in most of the Asian countries.

\section{Material and Method}

\subsection{Plant material}

Leaves of Morus alba L. were collected from rural area of Bhopal (M.P), India in the months of September 2015. These herbs were authenticated by Dr. Zea Ul Hasan,H O D , Department of Botany, Safia College, Bhopal and preserved in the herbarium (specimen No. 355/Bot./Safia/15)of the Dept. of Botany Safia College, Bhopal (M.P.)

Extraction procedure (Mukharjee, 2007).

Following procedure was adopted for the preparation of methanol extracts from the shade dried and powdered herbs:

\subsection{Defatting of Plant Material}

Powdered leaf material of Morus alba L. were shade dried at room temperature. The shade dried leaf material was coarsely powdered and subjected to extraction with petroleum ether in a soxhlet apparatus. The extraction was continued till the defatting of the material had taken place.

\subsection{Extraction by hot continuous percolation process}

50 g. of Morus alba L.dried leaves were exhaustively extracted with various solvent Chloroform, Ethyl Acetate, Ethanol and water and using different drug: solvent ratios using hot continuous percolation for different time. The extracts were evaporated above their boiling points finally the percentage yields were calculated of the dried extracts 


\section{International Journal of Science and Research (IJSR)}

ISSN (Online): 2319-7064

Index Copernicus Value (2013): 6.14 | Impact Factor (2015): 6.391

\subsection{Determination of Percentage yield}

Calculation of percentage yield

The percentage yield of yield of each extract was calculated by using formula:

$$
\text { Percentage yield }=\frac{\text { Weight of extract } \times 100}{\text { Weight of powdered drug take }}
$$

2.5 Qualitative Phytochemical Tests (Khandelwal, 2005, Kokate, 1994 and Tiwari et al., 2011)

The extracts were subjected to various qualitative tests to detect the presence of plant constituents. The results have been shown in table.

\subsubsection{Preparation of Test Solution}

The test solution was prepared by taking $1 \mathrm{~g}$ of the extract in $25 \mathrm{ml}$ of methanol.

\section{A. Test for Carbohydrates}

Following tests were carried out for carbohydrates.

a) Molisch's test: In a test tube containing extract of drug, added two drop of freshly prepared $20 \%$ alcoholic solution of $\alpha$ - napthol and mixed concentrated sulphuric acid along the sides of the test tube. If carbohydrate present purple color or reddish violet color produce at the junction between two liquids.

b) Benedict's test: In a test tube containing extract of drug add benedict's solution, mix well, boiled the mixture vigorously for two minutes and then cooled. Formation of red precipitate due to presence of carbohydrates.

c) Barfoed's test: The barfoed's solution added to $0.5 \mathrm{ml}$ of solution under examination, heated to boil. Formation of red precipitate of copper oxide was indicated the presence of carbohydrates.

d) Anthrone test: To the two $\mathrm{ml}$ of anthrone test solution, add the extract of drug. A green or blue colour indicated the presence of carbohydrate.

\section{B. Test for Alkaloids}

a) Dragendorff's Test: Few $\mathrm{mg}$ of extract of the drug dissolved in $5 \mathrm{ml}$ of water added $2 \mathrm{M}$ hydrochloric acid until an acid reaction occurred; $1 \mathrm{ml}$ of dragendorff's reagent (potassium bismuth iodide solution) was added an orange red precipitate indicated the presence of alkaloids.

b) Wagner's test: Acidify the extract of drug with $1.5 \%$ $\mathrm{v} / \mathrm{v}$ of hydrochloric acid and added a few drop of Wagner's reagent (iodine potassium iodide solution). Formations of reddish brown precipitate indicated the presence of alkaloids.

c) Mayer's Test: Two ml of extract solution was treated with 2 - 3 drops of Mayer's reagent was added (potassium mercuric iodide solution) formation of dull white precipitate indicated the presence of alkaloid.

d) Hager's Test: Extract of the drug solution was treated with $3 \mathrm{ml}$ of Hager's reagent (saturated solution of picric acid) formation of yellow precipitate confirmed the presence of alkaloids.

\section{Test for Steroids and Sterols}

a) Liebermann's Burchard reaction: The test extract solution was dissolved in $2 \mathrm{ml}$ of chloroform in a dry test tube. Now 10 drops of acetic anhydride and 2 drops of concentrated sulphuric acid were added. The solution became red, then blue and finally bluish green in color.

b) Salkowsky test: The extract of test solution dissolved in chloroform and equal volume of conc. sulphuric acid was added. Bluish red cherry, red and purple color was noted in chloroform layer, whereas acid assumes marked green fluorescence.

\section{Test for Glycosides}

a) Legal's test: Extract solution dissolved in pyridine then sodium nitroprusside solution was added to it and made alkaline. Pink red colour indicated the presence of glycosides.

b) Baljet's test: To the drug extract, sodium picrate solution was added, yellow to orange colour was indicated the presence of glycosides.

c) Borntrager's test: Few $\mathrm{ml}$ of dilute sulphuric acid solution, the test solution of extract was added. It was filtered and the filtrate was boiled with ether or chloroform. Then organic layer was separated to which ammonia was added, pink, red or violet colour was produced in orange layer confirmed the presence of glycosides.

d) Keller Kiliani test: Methanolic extract was dissolved in glacial acetic acid containing trace of ferric chloride one $\mathrm{ml}$ concentrated sulphuric acid was added carefully by the side of the test tube. A blue colour in the acetic acid layer and red colour at the junction of the two liquid indicated the presence of glycosides.

\section{E. Test of Saponins}

a) $1 \mathrm{ml}$ of alcoholic extract was diluted with $20 \mathrm{ml}$ distilled water and shaken in graduated cylinder for 15 minutes. One $\mathrm{cm}$ layer of foam indicated the presence of saponins.

\section{F. Test for Flavanoids}

Shinoda test: In the test tube containing alcoholic extract of the drug added 5 - 10 drops of dil. hydrochloric acid followed by the small piece of magnesium. In presence of flavonoids a pink, reddish pink or brown color was produced.

\section{G. Test for Tannins}

a) To the sample of the extract, ferric chloride solution was added appearance of dark blue or greenish black colour indicated the presence of tannins.

b) To the sample of extract, potassium cyanide was added, deep red colour was confirmed the presence of tannins.

c) To the sample of extract, potassium dichromate solution was added, yellow precipitate was produced.

\section{H. Test for Triterpenoids}

a) In the test tube, 2 or 3 granules of tin was added, and dissolved in $2 \mathrm{ml}$ of thionyl chloride solution and test solution was added. Pink colour was produced which indicates the presence of triterpenoids.

b) Two $\mathrm{ml}$ of acetic anhydride solution was added to $1 \mathrm{ml}$ of extract of drug in chloroform followed by one $\mathrm{ml}$ of conc. sulphuric acid, a violet colored ring was formed indicating presence of triterpinoid.

\section{Volume 5 Issue 6, June 2016 www.ijsr.net}




\section{International Journal of Science and Research (IJSR) \\ ISSN (Online): 2319-7064}

Index Copernicus Value (2013): 6.14 | Impact Factor (2015): 6.391

\section{Test for Protein and Amino acid}

a) Biuret's test: To $2-3 \mathrm{ml}$ of the extract of drug added in 1 $\mathrm{ml}$ of $40 \%$ sodium hydroxide solutions and 2 drops of 1 $\%$ copper sulphate solution mix thoroughly, a purplish violet or pinkish - violet colour produced that indicates the presence of proteins.

b) Ninhydrin's test: Two drops of freshly prepared $0.2 \%$ ninhydrin reagent was added to the extract and heated to boiling for $1-2 \mathrm{~min}$. and allow cooling. A blue colour developed that indicating the presence of proteins, peptides or amino acids.

c) Xanthoprotein test: To the extract in a test tube, add conc. nitric acid. A white precipitate was obtained and upon heating turns to yellow and cool the solution carefully. Added $20 \%$ of sodium hydroxide solution in excess orange colour indicated presence of aromatic amino acid.

d)Millon's test: The small quantity of extract of the drug dissolved in distilled water added 5 - 6 drop of millon's reagent. A white precipitate was formed which turned red on heating, indicated the presence of proteins.

e) Lead Acetate test: The extract was taken and two $\mathrm{ml}$ of 40 $\%$ sodium hydroxide solution was added and boiled, glacial acetic acid was added and cooled than added $1 \mathrm{ml}$ of lead acetate solution, gray black precipitate was formed which indicated presence of sulphur containing amino acid.

\section{J. Test of Resins}

Dissolved the extract in the acetone and pore the solution in the distilled water. Turbidity indicated the presence of resin.

\section{K. Test of Fats or Fixed oils}

a) Using sodium hydroxide: The extract was mixed in one ml $1 \%$ of copper sulphate solution then added $10 \%$ sodium hydroxide solution a clear blue solution was obtain which showed glycerin present in sample.

b)Using sodium hydrogen sulphate: The extract was taken in test tube added a pinch of sodium hydrogen sulphate pungent odour was formed which showed glycerin present in sample.

c) Saponification: Four ml of $2 \%$ sodium carbonate solution was taken and the extract was added. Shaked vigorously and boiled. A clean soapy solution was formed cooled and added few drops of conc. $\mathrm{HCl}$ and observed that fatty separate out and float up.

\section{Results and Discussion}

\section{Phytochemical Extraction and Preliminary Screening}

The different solvent extracts of the Morus alba L. leaves were subjected to preliminary qualitative assessment for the presence of alkaloids, glycosides, tannins, saponins, flavonoids, steroids and others separately according to Kokate's methods (1994). The results of phytochemical analysis are discussed in the (table 1). From the results, it is clear that the ethanolic leaves extract of Morus alba (L.) shows the presence of alkaloids, glycosides, phenols, flavonoids, amino acid and terpenoids, when extracted with different solvents using soxhlet extraction procedure.

Table 1: Results of Phytochemical Screening

\begin{tabular}{|l|l|c|l|l|l|l|}
\hline S.NO & \multicolumn{1}{|c|}{ Constituents } & $\begin{array}{c}\text { Pet. } \\
\text { Ether }\end{array}$ & Chloroform & Ethyl acetate & Ethanol & Aqueous \\
\hline 1 & Alkaloids & - & & - & + & + \\
\hline 2 & Glycosides & & & & + & + \\
\hline 3 & Flavonoids & - & & - & + & + \\
\hline 4 & Phenolics & - & - & + & + & + \\
\hline 5 & Carbohydrate & - & - & - & + \\
\hline 6 & Proteins & Saponins & - & - & + & + \\
\hline 7 & & - & - & + & + \\
\hline
\end{tabular}

\section{References}

[1] Arif T, Bhosale JD, Kumar N, Mandal TK, Bendre RS, Lavekar GS and Dabur R.,2009, Natural Productsantifungal agents derived from plants. Journal of Asian Natural Products Research., 7:621-638.

[2] Butt. M.S., A. Nazir, M.T. Sultan and K. Schroen, 2008, Morus alba L. nature's functional tonic, Trends Food Sci. Technol., 19: 505-512.

[3] Datta, R.K., 2000, Mulberry Cultivation and Utilization in India. FAO Electronic conference on mulberry for Animal Production (Morus 1-L), Mulberry cultivation and utilization in India. This electronic conference. Rome, Italy, pp: 45-62.

[4] Deshmukh, S.V., N.V. Pathak and D.A. Takalikar, 1993, Nutritional effect of mulberry (Morus alba) leaves as sole ration of adult rabbits, World Rabbit Sci. J., 1: 67-69.

[5] Dasilva EJ.,1999, Medicinal plants: a reemerging health aid, Electronic Journal of Biotechnology., 2:5770 .
[6] Gutierrez-Uribe, J.A., I. Romo-Lopez and S.O. Serna-Saldivar, 2011, Phenolic composition and mammary cancer cell inhibition of extracts of whole cowpeas (Vigna unguiculata) and its anatomical parts, J. Funct. Food., 3: 290-297.

[7] Khandelwal, K.R.,2005, Practical Pharmacognosy, Technique and Experiments, $23^{\text {rd }}$ Edn: 15- 29:149- 56.

[8] Kokate, C.K.,1994, Practical Pharmacognosy, 4th Edn., Vallabh Prakashan: 112-120.

[9] Kumar, V.R. and S. Chauhan, 2008, Mulberry: Life enhancer. J. Med. Plant. Res., 2: 271-278.

[10] Mohammadabadi, T. and M. Chaji, 2012, The Influence of the plant tannins on in vitro ruminal degradation and improving nutritive value of sunflower meal in ruminants. Pak. Vet. J., 32: 225-228.

[11] Mukherjee, P. K.,2007. "Quality Control of Herbal Drugs", $2^{\text {nd }}$ Edition, Business Horizons, 2-14.

[12] Nomura, T., T. Fukai and G. Kuwanon, 1980, A new flavone derivative from the root barks of the cultivated mulberry tree (Morus alba L.), Chem. Pharm. Bull., 28: 2548-2552. 


\section{International Journal of Science and Research (IJSR) \\ ISSN (Online): 2319-7064}

Index Copernicus Value (2013): 6.14 | Impact Factor (2015): 6.391

[13] Olufunmiso, Olajuyigbe, O. and Afolayan, Anthony, J. ,2011.. Phenolic Content and Antioxidant Property of the Bark Extract of Ziziphus mucronatawild. Subsp. Mucronata wild, BMC, Complementary and Alternative medicine; 11: 130.

[14] Sun, F., L.M. Shen and Z.J. Ma, 2011, Screening for ligands of human aromatase from mulberry (Mori alba L.) leaf by using highperformance liquid chromatography/ tandem mass spectrometry, Food Chem., 126: 1337-1343.

[15] Tiwari S. ,2008,Plants: a rich source of herbal medicines. Journal of Natural Products.1:27-35.

Volume 5 Issue 6, June 2016 www.ijsr.net 